\title{
Impedometric properties of the vulvar and vaginal tissues of ewes during the oestrous cycle
}

\author{
L. Adam, E. Aizinbud*, A. Tadmor $†$ and H. Schindler*
}

Department of Biomedical Engineering, School of Engineering, Tel Aviv University, Tel Aviv;

*Division of Reproduction, Institute of Animal Science, Agricultural Research Organization,

The Volcani Center, Bet Dagan; and † Kimron Veterinary Institute, Bet Dagan, Israel

\begin{abstract}
Summary. Tissue electrical conductance $(G)$ and capacitance $(C)$ were measured in vulvar and vaginal tissues of ewes by a spectroimpedographic method at frequencies from $10 \mathrm{~Hz}$ to $100 \mathrm{kHz}$. The calculated specific conductance $(\mu \mathrm{mho} / \mathrm{cm})$ at $100 \mathrm{kHz}$ was $3082 \pm 20$ (s.e.m.) in oestrus and $2153 \pm 16$ in dioestrus $(n=8)(P<0.001)$. The impedance angle and the tissue phase angle increased during oestrus, indicating that cell volume increased and cell density decreased in comparison with dioestrus. The ratio of conductivities at higher and lower frequencies showed that extracellular water content was maximal during oestrus and coincided with standing heat.
\end{abstract}

\section{Introduction}

Efforts to explain the factors responsible for the electrical properties of biological tissues (Cole, 1929, 1933; Fricke, 1933) have resulted in the development of frequency spectrum tissue impedography (Schwan, 1957, 1963; Adam, 1974). Spectrum bioimpedography permits structural analysis of living tissues, i.e. indirect determination of tissue components such as cell volume, cell density and extra- and intracellular fluid content.

Cyclic changes occur in the reproductive organs of non-pregnant ewes and cows with respect to morphological and cellular features, and fluid content of the tissues. This periodicity offers a unique opportunity to study the relationship between the structural changes and impedographic properties under physiological conditions. In a previous study (Feldmann, Aizinbud, Schindler \& Broda, 1978) we showed the feasibility of using implanted electrodes for measuring cyclic changes in the tissue impedance of the vaginal wall, but only one frequency was applied. It was the purpose of the present study to extend investigation of the impedographic changes occurring in the genital tissues by using frequency spectrum impedography in conjunction with chronically implanted electrodes. It was hoped that this new approach would reflect tissue changes, and thus the course of the oestrous cycle, with precision and sensitivity.

\section{Materials and Methods}

The 5 Finn-Merino crossbred ewes used for the experiments were 3-6 years old, weighed about $60 \mathrm{~kg}$ and were cycling regularly. To facilitate the observations, the oestrous cycles of the ewes were synchronized by a course of 13 daily i.m. injections of $15 \mathrm{mg}$ progesterone in oil followed by an injection of 500 i.u. PMSG. In cyclic ewes, this treatment does not impair fertility at the induced oestrus (O'Mary, Pope \& Casida, 1950) or affect its duration (Schindler, Amir \& Pinto, 
1977). The impedance measurements were made at 24 -h intervals during dioestrus and at 8 -h intervals from about 2 days before to about 2 days after oestrus. Oestrus, which was detected by means of aproned teaser rams at 8-h intervals, was defined as the period extending from $4 \mathrm{~h}$ before the first observation until $4 \mathrm{~h}$ after the last observation at which the ewe tolerated the mounting of the ram.

The ewes were housed in separate box stalls; when the measurements were made, the animals were tied to a stanchion.

\section{Surgery}

Pacemaker electrodes ('Elecath', Electro-Catheter Corp., Rahway, New Jersey) were implanted in all animals at the right side of the vulva; in 3 animals the electrodes were also placed in the left wall of the vagina.

After intramuscular injection of $0.5 \mathrm{ml}$ Rompun (Bayer A.G., Leverkusen), the ewes were restrained in ventral recumbency with the forelegs stretched towards the head and the hindquarters slightly elevated. To prevent defaecation during the operation, a pad was inserted into the rectum and fixed with a purse-string suture.

After cleaning and disinfection, a first incision $1.5-2.0 \mathrm{~cm}$ long was made in the skin of the right vulvar lip at a distance of about $0.5 \mathrm{~cm}$ lateral to the vulvar cleft. The subcutaneous tissue was undermined at a depth of about $8 \mathrm{~mm}$ to accommodate the electrode. A second incision 2.5-3 mm long was made in the skin of the left vulvar lip at a distance of about $0.5 \mathrm{~cm}$ lateral and parallel to the vulvar cleft. Subcutaneous tissue was undermined in the cranial direction in such a way that the tip of the electrode to be implanted could be placed in the vaginal submucosa about $0.5 \mathrm{~cm}$ proximal to the external urethral opening.

To prevent possible damage the electrode wires were led beneath the skin by pulling two electrodes stepwise through a subcutaneous tunnel starting at the shoulder in the sacral direction. There the tunnel was divided-one arm extending to the right vulvar incision and the other beneath the tail to the left vulvar incision so that the tips of the electrodes could reach their respective sites. There they were fixed in the tissue by sutures made immediately behind the ring contact. The correct position of the electrodes, i.e. their proximity to the mucosa and the absence of perforation, was verified by palpation from inside the vagina. The exit of the connectors was placed close to the base of the neck. Measurements were started not earlier than 3 weeks after the operation when the surgical wounds had healed completely.

\section{Impedometric principles and measurements}

Principles. The terminology of bio-impedography involves a serial resistance $(R)$, reactance $(X)$, and impedance $(Z,=R+j X)$. The parallel properties are conductance $(G)$, capacitance $(C)$, and admittance $(Y,=G+j \omega C)$ where $j=\sqrt{-1}$, the radial frequency, $\omega,=2 \pi f$, and $f$ is the frequency $(\mathrm{Hz})$. The capacitive properties are represented by $\omega \times C$. Generally, the electrical properties of a biological tissue in a cylindrical field configuration can be written as $G=\kappa(A / d)$ and $C=\varepsilon \cdot \varepsilon_{\mathrm{r}}(A / d)$ where $\kappa$ is the specific (per unit of tissue) conductance (conductivity), $\varepsilon$ is the specific dielectric constant of the tissue, $A$ is the electrode area in $\mathrm{cm}^{2}, d$ is the distance between the electrodes in $\mathrm{cm}$, and $\varepsilon_{\mathrm{r}}=(1 / 9) 10^{11} \cdot 4 \pi$.

Since capacitance, $C$, and conductance, $G$, are continuous and are frequency dependent, the total admittance, $Y$, can be presented conveniently in one multiple-variable plot showing the magnitude, $Y$, and phase $\theta$, of the admittance as a function of $\omega, C$ and $G$. Text-figure 1 shows that the conductance, $G$, increases continuously with increasing frequency and that $\omega C$ of the tissue increases to a peak and then declines. The capacitance, therefore, decreases with increasing frequency. 


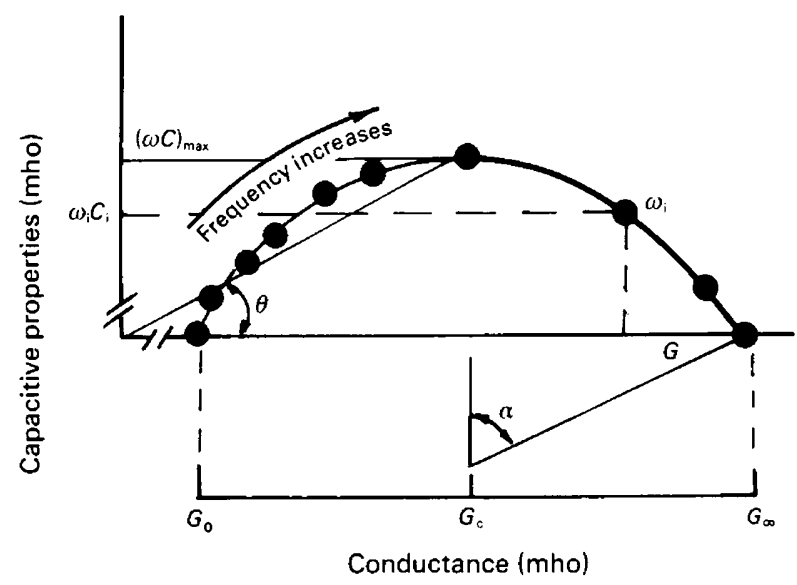

Text-fig. 1. Theoretical admittance plot of biological tissue.

A typical biological tissue displays 3 different relaxation processes, namely, the alpha, beta and gamma dispersions (Schwan, 1963). Each of them is defined by its initial $\left(G_{0}, \omega C_{0}\right)$ and final $\left(G_{\infty}, \omega C_{\infty}\right)$ admittance values and by its characteristic radial frequency at which the $\omega C$ reaches its peak value, designated as $(\omega C)_{\max }$, the characteristic capacitive property.

The parameters of an admittance plot can be useful in defining the behaviour or mechanisms of change in the tissue of interest. For example, assuming a spherical model (i.e. that the electrical field of a cell is dipolar) in Text-fig. 1, the conductance at the characteristic frequency, $G_{c}$, can be attributed to extracellular fluid content of the tissue, whereas the conductance at high frequency $\left(G_{\infty}\right)$ is associated with the total water content (Ducrot et al., 1970). The characteristic frequency separates between the frequencies at which currents penetrate the cell and the frequencies at which currents pass through the extracellular fluid. By applying Maxwell's theory to a biological tissue model (Schwan, 1957) it can be shown that the other useful characteristics are (i) the tissue membrane phase angle $(\alpha)$, which is associated with the distribution of the different sizes of cells in the tissue being examined and is inversely related to cell density, and (ii) the tissue admittance angle $(\theta)$, which serves for measurement of the cell volume.

Instrumentation and procedure. A 'current-null' method, instead of a standard 'voltage-null' method, was chosen because of its higher accuracy, faster speed of measurement, optional 2, 3 and 4 terminals impedography, and its excellent d.c. stability. The system designed and used (low frequency biological impedograph) permits precise determination of tissue conductance and capacitance for frequencies from $10 \mathrm{~Hz}$ to $100 \mathrm{kHz}$. It includes, in addition to the current-null bridge, a commercially available two-phase lock-in amplifier (PAR Company, Model 124, New Jersey) which is used as a phase-sensitive detector and as a signal generator. A detailed description of this system, its calibrations and measurement procedures appears elsewhere (Adam, 1974).

The measurements were performed at 10,100 and $500 \mathrm{~Hz}$ and at $1,5,10,13,50,70$ and 100 $\mathrm{kHz}$. All data were corrected for electrode polarization (Schwan, 1963).

\section{Results}

The kinetics of the specific conductance in the tissues of the vulva and vagina are shown in Text-fig. 2. In all cases, conductance started to increase on the day before oestrus, reached a peak at the middle or the last third of oestrus, and decreased to the dioestrous level 1 or 2 days thereafter. The course of the curve was similar in the vulvar and vaginal tissues, but the peak was 


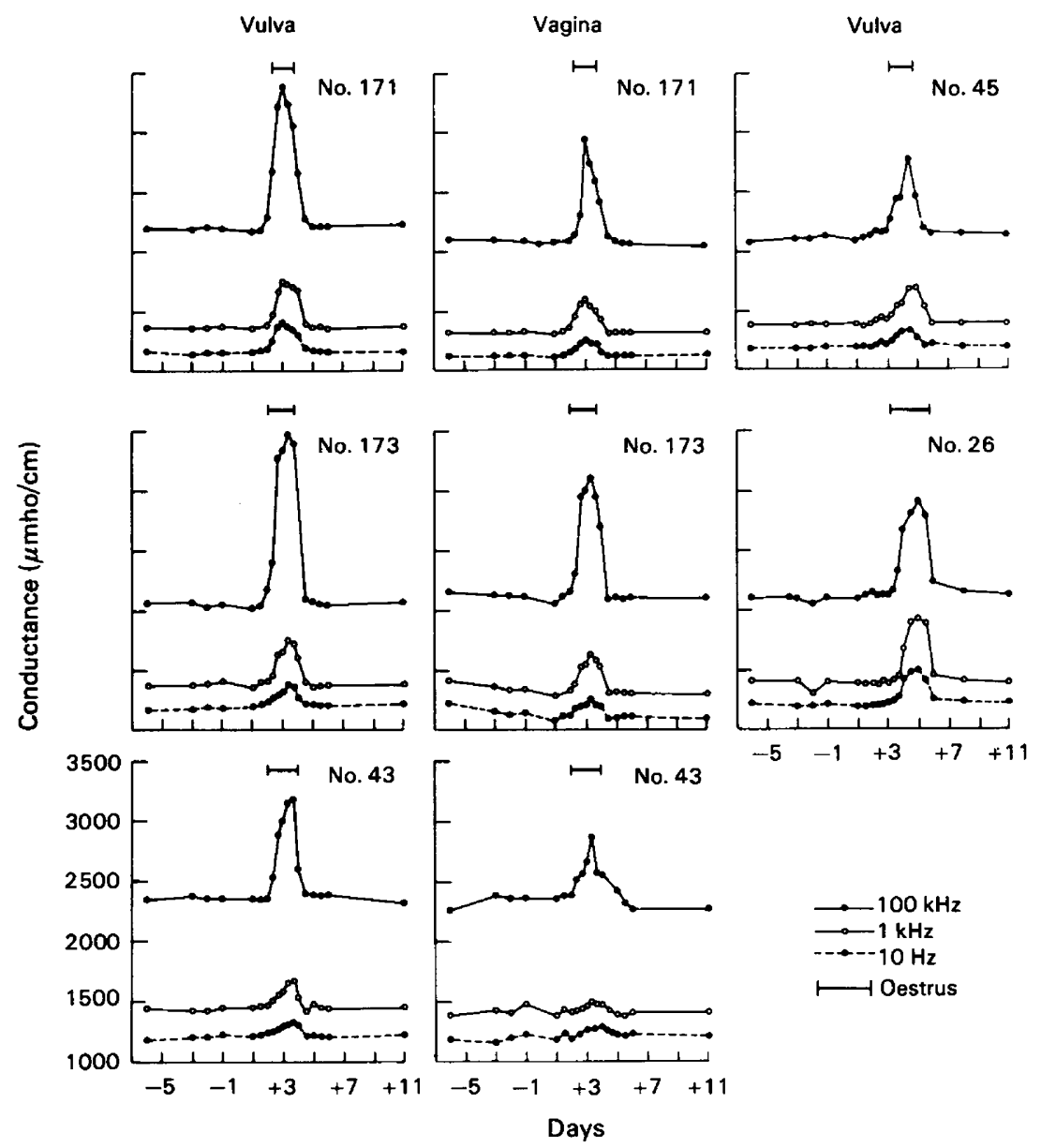

Text-fig. 2. The electrical specific conductance of the vulvar and vaginal submucosa in ewes.

Day 0 is the day of the last progesterone injection.

lower in the latter. The day-to-day variability of the basal measurements was small. The difference between the peak and the basal level of the specific conductance of the tissue increased with the rise in frequencies.

Representative admittance plots for the vulva measurements in oestrus and dioestrus for one ewe are shown in Text-fig. 3 and the combined results are given in Table 1. All values were higher at oestrus than at dioestrus.

\section{Discussion}

The increased conductance during oestrus is related to the hydration changes of the tissues studied. The oedema of the vaginal wall in ewes at oestrus has been noted by many workers, using histological methods, as reviewed by McKenzie \& Terrill (1937). It has also been confirmed by direct determination of the water content in mammalian genitalia during oestrus or after treatment with oestrogens (Steinetz, 1973; Finn \& Porter, 1975).

The simultaneous appearance of the peaks of conductivity in the two different sites of the genitalia shows that the oedema of subepithelial tissue at oestrus in the ewe takes place in all 


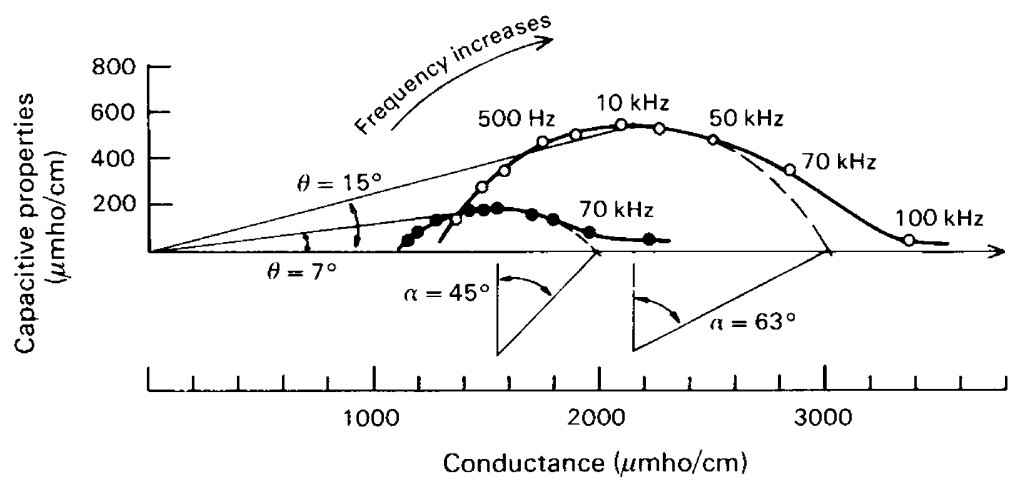

Text-fig. 3. Typical specific admittance plot of the vulvar submucosa of Ewe 171 during dioestrus $(O)$ and oestrus $(O)$.

Table 1. Electrical properties (mean \pm s.e.m.) of the vulvar ( 5 ewes) and vaginal ( 3 ewes) tissues during oestrus and dioestrus ( 8 th day of the cycle)

\begin{tabular}{|c|c|c|c|c|}
\hline & \multicolumn{2}{|c|}{ Vulvar tissue } & \multicolumn{2}{|c|}{ Vaginal tissue } \\
\hline & Oestrus & Dioestrus & Oestrus & Dioestrus \\
\hline \multicolumn{5}{|l|}{ Conductance $(\mu \mathrm{mho} / \mathrm{cm})$} \\
\hline at $10 \mathrm{~Hz}$ & $1372 \pm 30 \cdot 1$ & $1190 \pm 11 \cdot 8^{*}$ & $1251 \pm 10 \cdot 1$ & $1140 \pm 29 \cdot 5 \dagger$ \\
\hline at $1 \mathrm{kHz}$ & $1748 \pm 44 \cdot 2$ & $1397 \pm 15 \cdot 0^{*}$ & $1550 \pm 41.4$ & $1343 \pm 31 \cdot 1 t$ \\
\hline at $100 \mathrm{kHz}$ & $3158 \pm 126 \cdot 9$ & $2161 \pm 37 \cdot 6^{*}$ & $2956 \pm 76.4$ & $2141 \pm 63.9$ \\
\hline Characteristic capacitive property $(\mu \mathrm{mho} / \mathrm{cm})$ & $454.0 \pm 39.4$ & $182 \pm 4 \cdot 9^{*}$ & $424 \cdot 3 \pm 33 \cdot 6$ & $172.3 \pm 12.5 \dagger$ \\
\hline Tissue phase angle $\left({ }^{\circ}\right)$ & $60.8 \pm 1.9$ & $46 \pm 0.51^{*}$ & $60.7 \pm 1.2$ & $46.7 \pm 1.9 \dagger$ \\
\hline Tissue admittance angle $\left(^{\circ}\right)$ & $12.8 \pm 0.97$ & $6.8 \pm 0.20^{*}$ & $13.0 \pm 1.0$ & $7.3 \pm 0.4 \dagger$ \\
\hline Extracellular fluid $\%\left(G_{\infty} / G_{\mathrm{c}}=1\right)$ & $36.9 \pm 1.37$ & $26.9 \pm 0.34^{*}$ & $37.3 \pm 2.0$ & $27.7 \pm 0.65 \dagger$ \\
\hline
\end{tabular}

* Significantly different from value at oestrus, $P<0.001$ (Student's $t$ test).

$\dagger$ Significantly different from value at oestrus, $P<0.05$ (Student's $t$ test).

parts of the genital tract, as found by Brown (1944) for the cow. However, the fact that the peak of conductivity was higher in the vulvar tissue than in the vaginal wall indicates that the former contained more water. From the ratios of the high frequency conductance $\left(G_{\infty}\right)$ and the characteristic frequency conductance $\left(G_{c}\right)$, it became evident that the extracellular fluid content of the tissue studied was considerably higher during oestrus than during dioestrus. This is in agreement with similar findings obtained by biochemical methods (Steinetz, 1973). Current frequencies significantly influenced the sensitivity of the measurements. At $100 \mathrm{kHz}$ conductance values were $43 \%$ higher during the period of standing heat than during dioestrus, whereas at 1 $\mathrm{kHz}$ and $10 \mathrm{~Hz}$ they were $27 \%$ and $13 \%$ higher, respectively. This can be explained by the fact that measurements at $100 \mathrm{kHz}$ reflected changes of total fluid content in the tissues, whereas at the low frequencies only extracellular fluid was measured.

The decrease in cell density in the tissues during oestrus, evident from the increase of the tissue membrane phase angle, agrees with microscopic observations and it is associated with water accumulation in the extracellular spaces and in the epithelial cells themselves (Cole, 1930; McKenzie \& Terrill, 1937; Johnson, 1965). The higher density of cells at dioestrus is in accordance with the dense and fibrous vaginal stroma described by Cole (1930) for this stage of the cycle. The increase in cell volume during oestrus, as evident from the increased tissue admittance angle, conforms with morphological data such as swelling of the vaginal epithelial cells in cows (Hammond, 1927; Cole, 1930), increase in the height of the vaginal epithelium of ewes (Restall, 1966), and swelling of the cervical fibroblast cytoplasm in cows (Wrobel, 1971). 
In our studies there was a rise in the conductance, as expected, but also in the characteristic capacitative values of the genital tissues during oestrus, although the density of cells decreased. This may perhaps be explained by the significant rise in the number of mitochondria, i.e. insulative dielectric membranes of the connective tissue cells during oestrus which have been described by Wrobel (1971).

In the present work the peak of electrical conductivity inside the vulvar and vaginal tissues coincided with standing heat in all ewes (Text-fig. 2), whereas in our previous work (Feldmann, Aizinbud \& Schindler, 1976) the peak in the vaginal lumen coincided with standing heat only in $78 \%$ of the ewes and preceded it in $22 \%$. Intravaginal measurements are probably influenced by the amounts of cervico-vaginal mucus, which may be abundant before the onset of standing heat (Schindler \& Amir, 1972), whereas spectrum bioimpedographic measurements with implanted electrodes reflect structural changes and hydration of the tissue.

Measurements in the vaginal lumen have been reported as variable and not always reliable (Aizinbud, Davidson \& Shien, 1976; Gartland, Schiavo, Hall, Foote \& Scott, 1976). However, inside the tissue we found little variability, probably due to the fixed location of the implanted electrodes and their constant proximity to the surrounding tissue.

We suggest that impedometric principles can be used to develop a system for continuous recording of the oestrous cycle and perhaps as a farm technique for identifying oestrous cows in large commercial dairy herds. The technical problems will be simplified by the development of analogue telemetric systems, such as subdermal livestock electronic identification and temperature monitoring systems (Holm, Bobbett, Koelle, Landt \& Depp, 1977; Hooven, 1978).

We thank Mrs Dalya Peled (The Beilinson Medical Center), Mr D. Atlas, Mr N. Eliran (Tel-Aviv University), Mr I. Dimmerman, Mr Y. Brandstein and Mr H. Gacitua (Agricultural Research Organisation, Bet Dagan) for their continuous assistance during all phases of this study.

Contribution No. 269-E, 1978 series, from the Agricultural Research Organization, The Volcani Center, Bet Dagan, Israel.

\section{References}

Adam, L. (1974) Measurements of electrical properties of the cerebral cortex. Int. Biomed. J. 3, 152-155.

Aizinbud, E., Davidson, M. \& Shien, M. (1976) The electrical resistance in the vagina of normal cows and in those affected with endometritis. Refuah Vet. 33, 163.

Brown, P.C. (1944) Physiological and histological changes in the vagina of the cow during the estrual cycle. Am. J. vet. Res. 5, 99-112.

Cole, H.H. (1930) A study of the mucosa of the genital tract of the cow, with special reference to the cyclic changes. Am. J. Anat. 46, 261-301.

Cole, K.S. (1929) Electric impedance of suspensions of spheres. J. gen. Physiol. 12, 29-36.

Cole, K.S. (1933) Electrical conductance of biological systems. Cold Spring Harbor Symp. Quant. Biol. 1, 107-116.

Ducrot, H., Thomasset, A., Joly, R., Jungers, P., Eyraud, Ch. \& Lenoir, J. (1970) Détermination du volume des liquides extracellulaires chez l'homme par la mésure de l'impédance corporelle totale. Press Medical 78, 2269-2272.
Feldmann, F., Aizinbud, E. \& Schindler, H. (1976) The electrical conductivity in the vagina of ewes during the synchronisation of oestrus. Zuchthygiene 11, 1-6. (German with summary in English.)

Feldmann, F., Aizinbud, E., Schindler, H. \& Broda, H. (1978) The electrical conductivity inside the bovine vaginal wall. Anim. Prod. 26, 61-65.

Finn, C.A. \& Porter, D.G. (1975) The Uterus. Elek Science, London.

Fricke, H. (1933) The electric impedance of suspensions of biological cells. Cold Spring Harbor Symp. Quant. Biol. 1, 117-124.

Gartland, P., Schiavo, I., Hall, C.E., Foote, R.H. \& Scott, N.R. (1976) Detection of estrus in dairy cows by electrical measurements of vaginal mucus and by milk progesterone. J. Dairy Sci. 59, 982-985.

Hammond, J. (1927) The Physiology of Reproduction in the Cow. Cambridge University Press. (Cited by Cole, 1930.)

Holm, D.N., Bobbett, R.E., Koelle, A.R., Landt, J.A. \& Depp, S.W. (1977) Electronic identification. Los Alamos Scientific Laboratory of the University of 
California LA-7020-PR. Progress Report, UC-37, UC-48.

Hooven, N.W. (1978) Cow identification and recording systems. J. Dairy Sci. 60, 1167-1180.

Johnson, K.R. (1965) Cyclic histological changes occurring in the endometrium of the bovine. Res. Bull., Idaho Agric. Exp. Stn No. 63.

McKenzie, F.F. \& Terrill, C.E. (1937) Estrus, ovulation and related phenomena in the ewe. Res. Bull., Mo. Agric. Exp. Stn No. 264.

O'Mary, C.C., Pope, A.L. \& Casida, L.E. (1950) The use of progesterone in the synchronisation of the estrual periods in a group of ewes and the effect on their subsequent lambing records. J. Anim. Sci. 9, 499-503.

Restall, B.J. (1966) Histological observations on the reproductive tract of the ewe. Aust. J. biol. Sci. 19, 673-686.

Schindler, H. \& Amir, D. (1972) Length of oestrus, duration of phenomena related to oestrus and ovulation time in the local fat-tailed Awassi ewe. $J$. agric. Sci., Camb. 78, 151-156.
Schindler, H., Amir, D. \& Pinto, O. (1977) Oestrus synchronisation and breeding management in a sheep flock during the sexual season. Hassadeh 57, 916-919. (Hebrew, with English summary.)

Schwan, H.P. (1957) Electrical properties of tissue and cell suspensions. In Advances in Biological and Medical Physics, Vol. 5, pp. 147-209. Eds J. H. Lawrence \& C. A. Tobias. Academic Press, New York.

Schwan, H.P. (1963) Determination of biological impedances. In Physical Techniques in Biological Research, Vol. 6. Electrophysiological Methods, Part $B$, pp. 323-407. Ed. N. L. Nastuk. Academic Press, New York.

Steinetz, B.G. (1973) Secretion and function of ovarian estrogens. In Handbook of Physiology, Section 7, Endocrinology, Vol. 2. Part 1, pp. 439-466. Eds R. O. Greep \& E. B. Astwood. Am. Physiol. Soc., Washington, D.C.

Wrobel, K.H. (1971) Histologische, histochemische und elektronenmikroskopische Untersuchungen an der Cervix uteri des Rindes. Zentbl. VetMed. Suppl. 15.

Received 24 December 1979 